\title{
Rola przeszczepienia krwiotwórczych komórek macierzystych w leczeniu chorych na pierwotne chłoniaki skóry
}

\section{The role of hematopoietic stem cell transplantation in the treatment of patients with primary cutaneous lymphomas}

\author{
Włodzimierz Mendrek \\ Klinika Transplantacji Szpiku i Onkohematologii, Centrum Onkologii \\ — Instytut im. Marii Skłodowskiej-Curie, Oddział w Gliwicach
}

\begin{abstract}
Streszczenie
Pierwotne chtoniaki skóry sa heterogenna grupa nowotworów uktadu chtonnego, w większości wywodzacych sie z limfocytów T. Proces rozrostowy pierwotnie ogranicza sie do skóry, która może być jedyna lokalizacja choroby. Najczéściej przebiegaja w sposób przewlekty, ale uzyskanie wyleczenia rzadko jest możliwe, zwtaszcza w zaawansowanym stadium. W terapii stosuje się różne metodychirurgiczne, chemioterapię, radioterapię. Transplantacje krwiotwórczych komórek macierzystych należa do rzadko wykorzystywanych sposobów leczenia. Wskazania do zastosowania tych procedur opieraja sie gtównie na opiniach ekspertów oraz skąych danych klinicznych i rózniq sie zależnie od podtypu histopatologicznego.
\end{abstract}

Słowa kluczowe: pierwotne chłoniaki skóry, przeszczepienie krwiotwórczych komórek macierzystych, leczenie systemowe

Hematologia 2017; 8, 4: 280-288

\section{Abstract}

Primary cutaneous lymphomas are heterogeneous group of lymphoid neoplasms, mostly of T-cell origin; the primary proliferation being confined only to the skin. Cutaneous lymphomas usually run an indolent course but are rarely curable, particularly in advanced stages. Various treatments are adopted: surgery, chemotherapy and radiotherapy. Hematopoietic stem cell transplantation is used very rarely in treatment strategies. Indications for selecting any of such treatments are mostly based on expert opinion and limited clinical data, and they differ depending on histopathological subtype. Key words: primary cutaneous lymphoma, hematopoietic stem cell transplantation, systemic treatment

Hematologia 2017; 8, 4: 280-288

Adres do korespondencji: Włodzimierz Mendrek, Klinika Transplantacji Szpiku i Onkohematologii, Centrum Onkologii — Instytut im. Marii Skłodowskiej-Curie, Oddział w Gliwicach, ul. Wybrzeże Armii Krajowej 15, faks 3227891 49, 44-101 Gliwice, e-mail: wlodzimierz.mendrek@io.gliwice.pl 


\section{Wprowadzenie}

Pierwotne chłoniaki skóry są heterogenną grupą nowotworów układu chłonnego. W zdecydowanej większości przypadków (65-75\%) wywodzą się $z$ limfocytów T (CTCL, cutaneous T-cell lymphoma), rzadziej (ok. 25\% przypadków) - z limfocytów B (CBCL, cutaneous B-cell lymphoma), a wyjątkowo $-z$ komórek naturalnej cytotoksyczności (NK, natural killers). Chłoniaki definiuje się jako pierwotnie skórne, jeżeli przy rozpoznaniu proces rozrostowy jest ograniczony wyłącznie do skóry i nie stwierdza się zmian w węzłach chłonnych, szpiku czy narządach wewnętrznych. Aktualną klasyfikację tej grupy chłoniaków przedstawiono w tabeli $1[1,2]$.

Tabela 1. Klasyfikacja pierwotnych chłoniaków skóry według WHO-EORTC (Word Heath Organization - European Organization for Research and Treatment) (źródła [1, 2])

Table 1. Classification of primary cutaneous lymphoma according to WHO-EORTC (World Health organization - European Organization for Research and Treatment) (sources $[1,2])$

\begin{tabular}{|c|}
\hline Pierwotne chłoniaki skóry z komórek T i NK \\
\hline Chłoniaki o indolentnym przebiegu \\
\hline Ziarniniak grzybiasty (MF): \\
\hline - odmiana folikulotropowa MF \\
\hline - siatkowica pagetoidalna \\
\hline - skóra obwisła i ziarniniakowa \\
\hline $\begin{array}{l}\text { Pierwotny skórny chłoniak anaplastyczny z dużych } \\
\text { komórek T CD30+ }\end{array}$ \\
\hline Lymphomatoid papulosis \\
\hline Chłoniak z komórek T typu zapalenia tkanki podskórnej \\
\hline $\begin{array}{l}\text { Pierwotny skórny chłoniak z małych/średnich komórek } \\
\text { CD4+ }\end{array}$ \\
\hline Chłoniaki o agresywnym przebiegu \\
\hline Zespół Sezary'ego \\
\hline Chłoniak pozawęzłowy z komórek NK/T typu nosowego \\
\hline $\begin{array}{l}\text { Pierwotny skórny agresywny chłoniak epidermotropowy } \\
\text { z cytotoksycznych komórek CD8+ }\end{array}$ \\
\hline Pierwotny skórny chłoniak z komórek T $\gamma / \delta$ \\
\hline Chłoniak blastyczny z komórek NK \\
\hline Pierwotne chłoniaki skóry z komórek B \\
\hline Chłoniaki o indolentnym przebiegu \\
\hline Pierwotny skórny chłoniak strefy brzeżnej \\
\hline Pierwotny skórny chłoniak z ośrodków rozmnażania \\
\hline Chłoniaki o agresywnym przebiegu \\
\hline $\begin{array}{l}\text { Pierwotny skórny chłoniak rozlany z dużych komórek B } \\
\text { typu kończynowego }\end{array}$ \\
\hline Śródnaczyniowy chłoniak z dużych komórek B \\
\hline
\end{tabular}

Zdecydowaną większość przypadków stanowią ziarniniak grzybiasty (MF, mycosis fungoides) i zespół Sézary'ego (SS, Sézary syndrome). Pierwotne chłoniaki skóry zwykle przebiegają w sposób przewlekły, a do podtypów o agresywnym przebiegu zalicza się między innymi pierwotnego skórnego agresywnego chłoniaka epidermotropowego z komórek CD8 + czy pozawęzłowego chłoniaka $z$ komórek NK/T typu nosowego.

Rozpoznanie często bywa trudne i wymaga współdziałania lekarzy różnych specjalności w pierwszej kolejności dermatologów, ale także onkologów, hematologów i patomorfologów. Pierwotnego rozpoznania zwykle dokonuje dermatolog we współpracy z patomorfologiem, a podstawą rozpoznania jest badanie histopatologiczne dostępnego materiału tkankowego wspomagane diagnostyką immunohistochemiczną. Cały proces diagnostyczny wymaga nie tylko ustalenia rozpoznania, ale także stopnia zaawansowania, zgodnie $z$ klasyfikacją TNMB (Tumor-Nodes-Metastasis$-B l o o d)$. Właściwe rozpoznanie umożliwia dobranie optymalnej metody leczenia — od postępowania zachowawczego do bardzo intensywnego leczenia, w tym za pomocą przeszczepienia krwiotwórczych komórek macierzystych (HSCT, hematopoietic stem cell transplantation).

\section{Rola transplantacji w leczeniu pierwotnych chłoniaków skóry $\mathrm{z}$ komórek $\mathrm{T}$}

\section{Ziarniniak grzybiasty, zespół Sezary'ego}

Wśród pierwotnych chłoniaków skóry wywodzących się $z$ komórek T najczęstszym podtypem jest MF [1], który zwykle przebiega w sposób przewlekły, ale w przypadku progresji do postaci zaawansowanej jego przebieg może być bardzo agresywny [3]. Zespół Sezary’ego oznacza występowanie trzech objawów, tj. erytrodermii, uogólnionej limfadenopatii oraz obecność atypowych limfocytów T w skórze, węzłach chłonnych i krwi obwodowej. Częściej spotyka się postać de novo niż rozwijającą się na podłożu wcześniejszych zmian o charakterze MF.

W leczeniu wczesnych stadiów ziarniniaka grzybiastego (IA-IIA wg ISCL/EORTC [International Society For Cutaneous Lymphomas/ /European Organization for Research and Treatment] [1]) dostępnych jest wiele metod leczniczych: 1) terapia miejscowa glikokortykosteroidami, beksarotenem, karmustyną; 2) fototerapia - PUVA (psoralen plus ultraviolet $A$ ), UVB (ultraviolet $B$ ); 3 ) radioterapia pojedynczych 
zmian lub napromienianie całej skóry wiązką elektronów (TSEB, total skin electron beam); 4) fotofereza pozaustrojowa; 5) leczenie systemowe beksarotenem $\mathrm{w}$ formie doustnej, interferonem $\alpha$, metotreksatem, inhibitorami deacetylazy histonowej (HDACI, histone deacetylase inhibitors; np. worinostatem, romidepsyną), denileukinem diftitoks (stosowanym najczęściej po nieskutecznej terapii beksarotenem i/lub HDACI). W zaawansowanych stadiach MF (IIB-IVB wg ISCL/EORTC [1]), w przypadku nieskuteczności wyżej wymienionych form leczenia, oraz w SS do dyspozycji pozostaje leczenie systemowe $\mathrm{w}$ postaci monoterapii chlorambucylem, etopozydem, gemcytabiną, liposomalną doksorubicyną lub polichemioterapii (np. CHOP, cyklofosfamid, doksorubicyna, winkrystyna, prednizon; FC, fludarabina, cyklofosfamid; schematy $\mathrm{z}$ zastosowaniem arabinozydu cytozyny [Ara-C]) [4]. W aktualnych zaleceniach NCCN (National Comprehensive Cancer Network) wymieniane są także: brentuksymab vedotin, pentostatyna, inhibitory proteasomu (bortezomib), temozolomid (lek przeciwnowotworowy o działaniu alkilującym należący do grupy triazenów) czy pembrolizumab (humanizowane przeciwciało monoklonalne skierowane przeciwko receptorowi programowanej śmierci komórki 1 (PD-1, programmed cell death 1). Niestety, choć w większości przypadków leczenie pozwala na uzyskanie odpowiedzi, to jest ona zazwyczaj krótkotrwała [5-7].

Leczenie konwencjonalne postaci zaawansowanych nie ma charakteru radykalnego. Pozwala jedynie na czasową kontrolę choroby, bez perspektywy wyleczenia. W tej sytuacji uzasadnione jest rozważenie bardziej intensywnych form terapii, w tym leczenia wspomaganego przeszczepieniem autologicznych (auto-HSCT, autologous hematopoietic stem cell transplantation) lub allogenicznych (allo-HSCT, allogeneic hematopoietic stem cell transplantation) krwiotwórczych komórek macierzystych. Próby zastosowania terapii wysokodawkowej, wspomaganej auto-HSCT, nie przyniosły jednak satysfakcjonujących wyników. W dotychczasowych badaniach wykazano, co prawda, bezpieczeństwo procedury (nie opisywano śmiertelności zależnej od powikłań), jednak odległe wyniki dotyczące odpowiedzi na leczenie rozczarowały - $\mathrm{u}$ większości pacjentów szybko dochodziło do nawrotu i konieczności włączenia kolejnych linii leczenia. Dlatego też nie zaleca się auto-HSCT w leczeniu CTCL [8-10].

Zaletą allo-HSCT, oprócz możliwości zastosowania dużych dawek chemioterapii i/lub radioterapii, jest szansa wystąpienia immunologicznej reakcji przeszczep przeciwko chłoniakowi (GvL, graft-versus-lymphoma) [11]. Efektorami tej reakcji są pochodzące od dawcy limfocyty T. Dlatego allo-HSCT można traktować jako formę immunoterapii, $z$ intencją wyleczenia. W przypadku CTCL, zważywszy na brak prospektywnych badań klinicznych i ograniczoną liczbę danych pochodzących $z$ analiz retrospektywnych, rola allo-HSCT nie została jednak jednoznacznie zdefiniowana.

Jak dotąd, opisano kilka grup chorych na CTCL leczonych za pomocą allo-HSCT (tab. 2). W kondycjonowaniu stosowano zarówno schematy mieloablacyjne (MAC, myeloablative conditioning), na przykład TBI/Cy, czyli napromienienie całego ciała (TBI, total body irradiation) z następowym zastosowaniem cyklofosfamidu czy $\mathrm{Bu} / \mathrm{Cy}$ (busulfan, cyklofosfamid), jak i protokoły o zmniejszonej intensywności (RIC, reduced-intensity conditioning), na przykład Flu/Mel (fludarabina, melfalan. Dawcami krwiotwórczych komórek macierzystych było najczęściej zgodne w zakresie antygenów zgodności tkankowej (HLA, human leucocyte antigens) rodzeństwo lub zgodni w zakresie HLA dawcy niespokrewnieni (tab. 2) [12-15].

Molina i wsp. [12] przedstawili pracę obejmującą 8 chorych $z$ zaawansowanym MF/SS poddanych allo-HSCT. W leczeniu kondycjonującym stosowano zarówno schematy MAC, jak i RIC. Mimo opornej choroby $z$ nasilonymi objawami, uprzedniego zastosowania wielu linii leczenia, wszyscy uzyskali stan całkowitej remisji (CR) po allo-HSCT, a $6 \mathrm{z}$ nich pozostawało w remisji w 24., 35., 41., 50., 82. i 98. miesiącu po transplantacji [12].

Z kolei badanie Delioukiny i wsp. [13] dotyczyło pacjentów $z$ różnymi rodzajami CTCL. Wśród nich było 11 chorych $z$ rozpoznaniem zaawansowanego, opornego, pierwotnego chłoniaka skóry. U wszystkich pacjentów leczenie kondycjonujące miało charakter RIC. W tej grupie chorych prawdopodobieństwo przeżycia całkowitego (OS, overall survival) oraz przeżycia wolnego od progresji (PFS, progression-free survival) po 2 latach wyniosło $45 \%$. Śmiertelność z przyczyn innych niż nawrót (NRM, non-relapse mortality) po 2 latach oceniono na $27 \%$ [13].

Paralkar i wsp. [14] opublikowali wyniki badania obejmującego 12 pacjentów $z$ rozpoznaniem zaawansowanego, opornego na leczenie MF/SS, których poddano allo-HSCT. U 10 chorych w kondycjonowaniu zastosowano RIC. Po allo-HSCT uzyskano CR u połowy pacjentów. Mediana czasu wolnego od zdarzeń (EFS, event-free survival) u wszystkich pacjentów wyniosła 5,3 miesiąca, a szacowane 2-letnie OS - 58\% [14]. 
Tabela 2. Przeszczepienie allogenicznych krwiotwórczych komórek macierzystych u chorych na ziarniniaka grzybiastego/zespół Sézary'ego (opracowano na podstawie [12-15])

Table 2. Allogeneic hematopoietic stem cell transplantation in patients with mycosis fungoides/Sézary syndrome (developed based on [12-15])

\begin{tabular}{|c|c|c|c|c|c|}
\hline Piśmiennictwo & Pacjent & Kondycjonowanie & $\begin{array}{l}\text { Profilaktyka } \\
\text { GvHD }\end{array}$ & $\begin{array}{l}\text { Źródło komórek } \\
\text { do transplantacji }\end{array}$ & Wynik, stan choroby \\
\hline Molina i wsp. [12] & $\begin{array}{l}1 . \\
2 . \\
3 . \\
4 . \\
5 . \\
6 . \\
7 . \\
8 .\end{array}$ & $\begin{array}{l}\text { TBI/Cy } \\
\text { TBI/Cy } \\
\text { TBI/Cy } \\
\text { Bu/Cy } \\
\text { Flu/Mel } \\
\text { Flu/Mel } \\
\text { Flu/Mel } \\
\text { Flu/Mel }\end{array}$ & $\begin{array}{c}\text { CSA/Mtx MPL } \\
\text { CSA/Mtx MPL } \\
\text { CSA/MMF } \\
\text { CSA/MMF } \\
\text { CSA/MMF } \\
\text { CSA/MMF } \\
\text { CSA/MMF MPL } \\
\text { CSA/MMF MPL }\end{array}$ & $\begin{array}{l}\text { MUD BM } \\
\text { Sib BM } \\
\text { Sib PBSC } \\
\text { Sib PBSC } \\
\text { Sib PBSC } \\
\text { MUD BM } \\
\text { MUD BM } \\
\text { MUD PBSC }\end{array}$ & $\begin{array}{c}\text { Żyje w 108. miesiącu, CR } \\
\text { Żyje w 89. miesiącu, CR } \\
\text { Zgon w CR w 16. miesiącu } \\
\text { Żyje w 60. miesiącu, CR } \\
\text { Żyje w 53. miesiącu, CR } \\
\text { Żyje w 45. miesiącu, CR } \\
\text { Żyje w 33. miesiącu, CR } \\
\text { Zgon; infekcja w +34. dniu }\end{array}$ \\
\hline Delioukina i wsp. [13] & $\begin{array}{l}1 . \\
2 . \\
3 . \\
4 . \\
5 . \\
6 . \\
7 . \\
8 . \\
9 . \\
10 . \\
11 .\end{array}$ & $\begin{array}{l}\text { Flu/Mel } \\
\text { Flu/Mel } \\
\text { Flu/Mel } \\
\text { Flu/Mel } \\
\text { Flu/Mel } \\
\text { Flu/Mel } \\
\text { Flu/Mel } \\
\text { Flu/Mel } \\
\text { Flu/Mel } \\
\text { Flu/Mel } \\
\text { Flu/Mel }\end{array}$ & $\begin{array}{c}\text { Siro/Tacro/Mtx } \\
\text { CSA/MMF/Mtx } \\
\text { CSA/MMF/ATG } \\
\text { CSA/MMF } \\
\text { CSA/MMF/Mtx } \\
\text { Siro/Tacro } \\
\text { Siro/Tacro } \\
\text { Siro/Tacro } \\
\text { Siro/Tacro } \\
\text { CSA/MMF } \\
\text { Siro/Tacro }\end{array}$ & $\begin{array}{l}\text { MUD } \\
\text { MUD } \\
\text { MUD } \\
\text { MUD } \\
\text { MUD } \\
\text { Sib } \\
\text { Sib } \\
\text { Sib } \\
\text { Sib } \\
\text { Sib } \\
\text { Sib }\end{array}$ & $\begin{array}{c}\text { Wznowa } w+72 \text {. dobie, } \\
\text { zgon } w+213 \text {. dobie } \\
\text { Zgon } w+34 \text {. dobie } \\
\text { Zgon } w+91 \text {. dobie } \\
\text { bd } \\
\text { bd } \\
\text { bd } \\
\text { bd } \\
\text { PD } w+48 \text {. dobie, zgon } w \\
+67 . \text { dobie } \\
\text { Wznowa } w+147 \text {. dobie, } \\
\text { zgon } w+238 \text {. dobie } \\
\text { Zgon } w+3165 \text {. dobie } \\
\text { Zgon } w+71 \text {. dobie }\end{array}$ \\
\hline Paralkar i wsp. [14] & $\begin{array}{l}1 . \\
2 . \\
3 . \\
4 . \\
5 . \\
6 . \\
7 . \\
8 . \\
9 . \\
10 . \\
11 . \\
12 .\end{array}$ & $\begin{array}{l}\mathrm{Flu} / \mathrm{Cy} \\
\mathrm{Flu} / \mathrm{Bu} \\
\mathrm{Flu} / \mathrm{Mel} \\
\mathrm{Cy} / \mathrm{TBI} \\
\mathrm{Cy} / \mathrm{TBI} \\
\mathrm{Flu} / \mathrm{Bu} \\
\mathrm{Flu} / \mathrm{Bu} \\
\mathrm{Flu} / \mathrm{Bu} \\
\mathrm{Flu} / \mathrm{Bu} \\
\mathrm{Flu} / \mathrm{Bu} \\
\mathrm{Flu} / \mathrm{Bu} \\
\mathrm{Flu} / \mathrm{Bu}\end{array}$ & $\begin{array}{l}\mathrm{bd} \\
\mathrm{bd} \\
\mathrm{bd} \\
\mathrm{bd} \\
\mathrm{bd} \\
\mathrm{bd} \\
\mathrm{bd} \\
\mathrm{bd} \\
\mathrm{bd} \\
\mathrm{bd} \\
\mathrm{bd} \\
\mathrm{bd}\end{array}$ & $\begin{array}{l}\text { Sib } \\
\text { Sib } \\
\text { Sib } \\
\text { Sib } \\
\text { Sib } \\
\text { Sib } \\
\text { Sib } \\
\text { MUD } \\
\text { URD MM } \\
\text { MUD } \\
\text { MUD } \\
\text { MUD }\end{array}$ & $\begin{array}{c}\text { PD } \\
\text { PD } \\
\text { Żyje w 45. miesiącu, CR } \\
\text { Żyje w } 39 \text { miesiącu, CR } \\
\text { Wczesny zgon } \\
\text { PD } \\
\text { Żyje w 27. miesiącu, AD } \\
\text { Żyje w 22. miesiącu, CR } \\
\text { Zgon w CR } \\
\text { Wczesny zgon } \\
\text { Żyje w 16. miesiącu, CR } \\
\text { Żyje w 13. miesiącu, CR }\end{array}$ \\
\hline Duvic i wsp. [15] & $\begin{array}{l}1 . \\
2 . \\
3 . \\
4 . \\
5 . \\
6 . \\
7 . \\
8 . \\
9 . \\
10 . \\
11 . \\
12 . \\
13 . \\
14 . \\
15 . \\
16 . \\
17 . \\
18 . \\
19 .\end{array}$ & $\begin{array}{c}\text { EB/Flu/Cy/ATG } \\
\text { Flu/Cy/Ritux/EB } \\
\text { Flu/Bu/ATG } \\
\text { EB/Flu/Mel } \\
\text { EB/Flu/Mel } \\
\text { EB/Flu/Mel } \\
\text { EB/Flu/Mel } \\
\text { EB/Flu/Mel/ATG } \\
\text { EB/Flu/Mel } \\
\text { EB/Flu/Mel } \\
\text { EB/Flu/Mel/ATG } \\
\text { EB/Flu/Mel/ATG } \\
\text { EB/Flu/Mel } \\
\text { EB/Flu/Mel } \\
\text { Flu/Mel/ATG } \\
\text { Flu/Mel/ATG } \\
\text { EB/Flu/Mel/ATG } \\
\text { EB/Flu/Mel/ATG } \\
\text { EB/Flu/Mel }\end{array}$ & $\begin{array}{l}\text { bd } \\
\text { bd } \\
\text { bd } \\
\text { bd } \\
\text { bd } \\
\text { bd } \\
\text { bd } \\
\text { bd } \\
\text { bd } \\
\text { bd } \\
\text { bd } \\
\text { bd } \\
\text { bd } \\
\text { bd } \\
\text { bd } \\
\text { bd } \\
\text { bd } \\
\text { bd } \\
\text { bd }\end{array}$ & $\begin{array}{c}\text { bd } \\
\text { Sib PBSC } \\
\text { Sib MM BM } \\
\text { Sib PBSC } \\
\text { Sib PBSC } \\
\text { Sib PBSC } \\
\text { Sib PBSC } \\
\text { URD MM BM } \\
\text { Sib PBSC } \\
\text { Sib PBSC } \\
\text { URD MM BM } \\
\text { MUD PBSC } \\
\text { Sib PBSC } \\
\text { Sib (źródło bd) } \\
\text { URD MM PBSC } \\
\text { URD MM PBSC } \\
\text { URD MM BM } \\
\text { URD MM PBSC } \\
\text { Sib PBSC }\end{array}$ & $\begin{array}{l}\text { Żyje w 99. miesiącu, PR } \\
\text { Żyje w 91. miesiącu, CR } \\
\text { Żyje w 89. miesiącu, CR } \\
\text { Żyje w 87. miesiącu, CR } \\
\text { Zgon w 42. miesiącu w CR } \\
\text { Zgon w 27. miesiącu w CR } \\
\text { Zgon w 9. miesiącu w PD } \\
\text { Zgon w +16. dobie, sepsa } \\
\text { Zgon w 13. miesiącu w CR } \\
\text { Żyje w 54. miesiącu w CR } \\
\text { Żyje w 44. miesiącu w CR } \\
\text { Żyje w 26. miesiącu w CR } \\
\text { Żyje w 22. miesiącu w CR } \\
\text { Żyje w 20. miesiącu w CR } \\
\text { Żyje w 19. miesiącu w SD } \\
\text { Żyje w 15. miesiącu w CR } \\
\text { Żgon w 5. miesiącu w PD } \\
\text { Żyje w 14. miesiącu w CR } \\
\text { Żyje w 14. miesiącu w CR }\end{array}$ \\
\hline
\end{tabular}

TBI (total body irradiation) - napromienianie całego ciała; Cy - cyklofosfamid; CSA - cyklosporyna; Mtx (methotrexate) - metotreksat; MUD (matched unrelated donor) - zgodny dawca niespokrewniony; BM (bone marrow) - szpik kostny; CR - całkowita remisja; MPL — metylprednizolon; Sib (sibling donor) - zgodny dawca rodzinny; PBSC (peripheral blood stem cells) — komórki macierzyste z krwi obwodowej; Bu — busulfan; Flu — fludarabina; MMF — mykofenolan mofetilu; Siro — sirolimus; Tacro (tacrolimus) - takrolimus; ATG (antithymocyte globulin) - globulina antytymocytowa; bd - brak danych; PD (progression of disease) - progresja choroby; Mel — melfalan; AD (active disease) — aktywna choroba; EB (electron beam) — napromienianie skóry elektronami; URD MM (mismatched unrelated donor) — nie w pełni zgodny dawca niespokrewniony; PR (partial remission) - częściowa remisja 
Duvic i wsp. [15] opisali 19 chorych na zaawansowanego CTCL, u których zastosowano nieco odmienną od innych strategię leczenia. W pierwszej fazie wykorzystano TSEB jako leczenie zmniejszające masę guza (napromienianie wykonano 1-2 miesiące przed transplantacją), a następnie pacjentów poddano allo-HSCT $z$ kondycjonowaniem RIC. Całkowitą remisję uzyskano u 58\% chorych. Prawdopodobieństwo 2-letniego OS oceniono na $79 \%$, a PFS - na $53 \%$. $Z$ jednej strony wyniki wskazują, że dołączenie radioterapii $\mathrm{w}$ formie TSEB pozwoliło istotnie zmniejszyć masę guza oraz uzyskać poprawę wyników leczenia. $Z$ drugiej strony mogło także wpłynąć na zmniejszenie nasilenia objawów skórnej postaci choroby przeszczep przeciwko gospodarzowi (GvHD, graft-versus-host disease).

$\mathrm{W}$ ostatnich latach wyniki transplantacji w MF/SS opublikowały EBMT (The European Group for Blood and Marrow Transplantation) i CIBMTR (Center for International Blood and Marrow Transplantation Research) [10, 16, 17].

W 2008 roku Duarte i wsp. [10] przedstawili dane dotyczące między innymi allo-HSCT u pacjentów $z$ rozpoznaniem MF/SS. Już pierwszy przypadek z 1994 roku pokazał, że możliwe jest uzyskanie długotrwałego PFS (6 lat) po allo-HSCT u pacjenta z zaawansowaną postacią MF. Dalej przytoczono wyniki leczenia 10 pacjentów, u których wykorzystano MAC. W momencie publikacji 8 chorych nadal żyło bez cech choroby (mediana obserwacji 57 miesięcy). Zwrócono uwagę, że u prawie wszystkich pacjentów wystąpily objawy ostrego GvHD (1 pacjent zmarl), a u 6 z 8 - objawy przewlekłego GvHD. Autorzy zasugerowali, że MAC jest możliwe do wykorzystania jedynie u młodszych osób. Przedstawiono również kilka innych doniesień opisujących pacjentów, u których w kondycjonowaniu wykorzystano RIC. Łącznie opisano 7 chorych w wieku 38-60 lat z zaawansowanymi postaciami MF/SS, których poddano allo-RIC-HSCT. Sześciu z nich uzyskało CR, która utrzymywała się nawet do 28 miesięcy po transplantacji (2 pacjentów zmarło w CR w czasie krótszym niż rok po przeszczepieniu). Jeden chory uzyskała częściową remisję (PR, partial remission), a następnie zmarł po 11 miesiącach $z$ powodu progresji choroby i przewlekłej postaci GvHD. U wszystkich długo obserwowanych chorych rozwinęła się najpierw ostra, a u większości także przewlekła postać GvHD. Sugeruje to obecność zjawiska GvL, także w przypadku zastosowania RIC [10]. W ostatniej części dotyczącej zaawansowanych postaci MF/SS przedstawiono wyniki leczenia kolejnej grupy 15 pacjentów poddanych allo-RIC-HSCT. W leczeniu kondycjonującym u wszystkich chorych zastosowano TBI $(2 \mathrm{~Gy}$ ) wraz z pentostatyną, fludarabiną i cyklofosfamidem $\mathrm{w}$ jednej grupie protokołu leczniczego, a w drugiej - wyłącznie $z$ pentostatyną w przypadku dawcy rodzinnego lub $z$ fludarabiną, melfalanem i alemtuzumabem w przypadku dawcy niespokrewnionego. Przy medianie obserwacji wynoszącej 41 miesięcy 9 pacjentów pozostawało w CR z prawdopodobieństwem 5-letniego PFS na poziomie $60 \%$. Wyniki te należy uznać za bardzo zachęcające [10].

W 2014 roku ponownie Duarte i wsp. [16] przedstawili wyniki leczenia 60 pacjentów $z$ rozpoznaniem zaawansowanej postaci MF/SS zgłoszonych do EBMT, których poddano allo-HSCT w latach 1995-2007. Źródłem komórek krwiotwórczych byli dawcy rodzinni (45 przypadków) lub niespokrewnieni (15 przypadków). W momencie rozpoznania u $73 \%$ badanych choroba miała IV stopień zaawansowania, a w momencie transplantacji u $67 \%$ nadal stwierdzano zaawansowaną postać MF/SS. Jedynie 27\% pacjentów otrzymało MAC. Wyniki leczenia były następujące: 5-letnie OS $46 \%$, 7-letnie OS - 44\%, 5-letnie PFS - 32\%, 7-letnie PFS - 30\%. Główną przyczyną niepowodzenia allo-HSCT była wznowa/progresja choroby. Stwierdzono ją u 27 pacjentów z medianą 3,8 miesiąca po transplantacji (zakres 1-59 miesięcy). Na wyniki transplantacji niekorzystnie wpłynęły większe zaawansowanie choroby, transplantacja od niespokrewnionego dawcy, MAC, zły stan ogólny pacjenta oraz T-deplecja materiału przeszczepowego. W konkluzji autorzy podkreślają, że allo-HSCT stanowi ważną opcję leczniczą pacjentów z zaawansowanymi postaciami MF/SS, zwłaszcza dzięki efektowi GvL [16].

Jednym $z$ największych opracowań dotyczących wykorzystania allo-HSCT w leczeniu MF/ /SS jest praca Lechowicza i wsp. [17] oparta na danych 129 pacjentów leczonych allo-HSCT w latach 2000-2009 i zgłoszonych do CIBMTR. U 64\% chorych w kondycjonowaniu zastosowano leczenie niemieloablacyjne (NST, non-myeloablative conditioning) lub RIC, pozostali otrzymali MAC. Później niż 12 miesięcy od daty diagnozy transplantacji poddano $80 \%$ pacjentów; $37 \%$ nigdy nie uzyskało $\mathrm{CR}$ w trakcie leczenia. Głównym źródłem komórek krwiotwórczych (86\%) była krew obwodowa, co jest zbieżne $z$ danymi dotyczącymi wykorzystania allo-HSCT w leczeniu innych chorób. Schematy kondycjonujące NST/RIC były oparte głównie $(80 \%)$ na fludarabinie. W przypadku MAC najczęściej (35\%) łączono cyklofosfamid z TBI. Niezależnie od rodzaju zastosowanego kondycjonowania OS 
Tabela 3. Wyniki przeszczepień allogenicznych krwiotwórczych komórek macierzystych u chorych na ziarniniaka grzybiastego/zespół Sézary'ego według CIBMTR (Center for International Blood and Marrow Transplantation Research) (2000-2009) (źródło [17])

Table 3. Results of allogeneic hematopoietic stem cell transplantation in patients with mycosis fungoides/Sézary syndrome according to the CIBMTR (Center for International Blood and Marrow Transplantation Research) (2000-2009) (source [17])

\begin{tabular}{|c|c|c|c|c|}
\hline Wyniki transplantacji & $\mathbf{n}$ & RIC/NST & $\mathbf{n}$ & MAC \\
\hline $\begin{array}{l}\text { Śmiertelność: } \\
\text { - w 30. dobie } \\
\text { - w 100. dobie }\end{array}$ & 82 & $\begin{array}{c}5(1-11) \\
15(8-23)\end{array}$ & 45 & $\begin{array}{c}9(2-19) \\
18(8-31)\end{array}$ \\
\hline $\begin{array}{l}\text { NRM: } \\
\text { - w 1. roku } \\
\text { - w 3. roku } \\
\text { - w 5. roku }\end{array}$ & 77 & $\begin{array}{c}16(9-26) \\
20(11-30) \\
20(11-30)\end{array}$ & 42 & $\begin{array}{l}24(12-38) \\
27(14-42) \\
27(14-42)\end{array}$ \\
\hline $\begin{array}{l}\text { Progresja: } \\
\text { - w 1. roku } \\
\text { - w 3. roku } \\
\text { - w 5. roku }\end{array}$ & 77 & $\begin{array}{l}50(39-62) \\
57(45-69) \\
57(45-69)\end{array}$ & 42 & $\begin{array}{l}50(35-66) \\
60(44-75) \\
67(49-82)\end{array}$ \\
\hline $\begin{array}{l}\text { PFS: } \\
\text { - w 1. roku } \\
\text { - w 3. roku } \\
\text { - w 5. roku }\end{array}$ & 77 & $\begin{array}{l}33(23-45) \\
23(13-35) \\
23(13-35)\end{array}$ & 42 & $\begin{array}{c}26(13-41) \\
13(4-26) \\
6(0-21)\end{array}$ \\
\hline $\begin{array}{l}\text { OS: } \\
\text { - w 1. roku } \\
\text { - w 3. roku } \\
\text { - w 5. roku }\end{array}$ & 83 & $\begin{array}{l}56(45-67) \\
41(29-53) \\
36(23-50)\end{array}$ & 46 & $\begin{array}{c}51(35-66) \\
31(16-49) \\
21(5-43)\end{array}$ \\
\hline
\end{tabular}

RIC (reduced-intensity conditioning) — kondycjonowanie o zmniejszonej intensywności; NST (non-myeloablative stem cell transplantation) — kondycjonowanie niemieloablacyjne; MAC (myeloablative conditioning) — kondycjonowanie mieloablacyjne; NRM (non-relapse mortality) — śmiertelność niezwiązana z progresją; PFS (progression-free survival) - przeżycie wolne od progresji, OS (overall survival) - całkowite przeżycie

oceniono na $54 \%, 38 \%$ i $32 \%$ odpowiednio w 1 ., 3. i 5. roku po transplantacji. W opisywanej grupie pacjentów NRM wyniósł 19\% w 1. roku i $22 \%$ w 5. roku. Progresja/wznowa choroby wystąpiła u $50 \%$ chorych w 1 . roku, a u $61 \%$ w 5 . roku. Szacowane roczne PFS wyniosło $31 \%$, a 5-letnie $-17 \%$. U 41\% pacjentów obserwowano GvHD w stadium II-IV według ISCL/EORTC [1]. Częstość występowania postaci przewlekłej GvHD oceniono na 33\%, $42 \%$ i $43 \%$ odpowiednio w 180 . dniu, w 1 . i 2 . roku. Główną przyczyną zgonu była progresja choroby [17]. Dane $z$ uwzględnieniem rodzaju leczenia kondycjonującego przedstawiono w tabeli 3. Autorzy oceniają, że allo-HSCT jest użyteczną metodą leczenia MF/SS, zwłaszcza w zaawansowanej postaci choroby, z NRM pozostającym w akceptowalnych granicach (19-28\%). Zaznaczają jednak, że mimo przewagi allo-HSCT nad innymi metodami leczenia wznowa choroby pozostaje główną przyczyną zgonów pacjentów.

W opinii ekspertów grupą pacjentów, u których powinno się rozważyć allo-HSCT, są chorzy młodzi, w dobrym stanie ogólnym, bez istotnych obciążeń podwyższających ryzyko przeprowadzenia takiego leczenia, $z$ chorobą $w$ fazie zaawansowanej (IIB-IVB wg ISCL/EORTC [1]). u których przeszczepienie będzie traktowane jako konsolidacja uzyskanej innymi metodami PR lub CR. Należy jednak podkreślić, że częstość infekcji, wznów choroby czy śmiertelność $z$ powodów innych niż progresja/ /nawrót jest w tej grupie względnie wysoka. Jednak, niezależnie od wyżej opisanego ryzyka allo-HSCT, obecnie wydaje się jedyną metodą dającą szansę na wyleczenie MF/SS [4, 10, 12-18].

\section{Chłoniak z komórek T tkanki podskórnej typu zapalenia tkanki podskórnej}

Chłoniak $z$ komórek T typu zapalenia tkanki podskórnej (SPTCL, subcutaneous panniculitis-like T-cell lymphoma) jest rzadkim chłoniakiem występującym zarówno u dorosłych, jak i dzieci. Najczęściej przebiega w sposób łagodny, a 5-letnie OS ocenia się jako zawarte w przedziale $55-81 \%$ [4]. U około $15 \%$ chorych SPTCL może być powikłany zespołem hemofagocytarnym, co wiąże się z szybką progresją choroby. $\mathrm{W}$ takich przypadkach w pierwszej linii leczenia stosuje się polichemioterapię CHOP, natomiast w przypadku oporności - DHAP (deksametazon, Ara-C, cisplatyna), ESHAP (etopozyd, glikokortykosteroidy, Ara-C, cisplatyna), FLAG (fludarabina, Ara-C) czy schematy $\mathrm{z}$ wykorzystaniem kladrybiny. Następnie, jako leczenie konsolidujące, przeprowadza się auto-HSCT $z$ krwi obwodowej. W leczeniu kondycjonującym stosuje się schematy leczenia oparte na chemioterapii, na przykład BEAM 
Tabela 4. Wskazania do transplantacji krwiotwórczych komórek macierzystych u chorych na pierwotne chłoniaki skóry Table 4. Recommendations for hematopoietic stem cell transplantation in patients with primary cutaneous lymphoma

\begin{tabular}{|c|c|c|}
\hline Typ nowotworu & auto-HSCT & allo-HSCT \\
\hline \multicolumn{3}{|c|}{ Pierwotne chłoniaki skóry z komórek T } \\
\hline $\begin{array}{l}\text { Mycosis fungoides/zespół } \\
\text { Sézary'ego }\end{array}$ & Brak wskazań & $\begin{array}{l}\text { Opcja lecznicza dla postaci zaawansowanej, pacjen- } \\
\text { tów w młodym wieku, w dobrym stanie ogólnym, bez } \\
\text { istotnych schorzeń towarzyszących }\end{array}$ \\
\hline $\begin{array}{l}\text { Chłoniak z komórek T tkanki } \\
\text { podskórnej typu zapalenia tkanki } \\
\text { podskórnej }\end{array}$ & $\begin{array}{l}\text { Opcja lecznicza w przypadku } \\
\text { współistnienia zespołu } \\
\text { hemofagocytarnego }\end{array}$ & $\begin{array}{l}\text { Brak wystarczających danych do rekomendowania } \\
\text { leczenia }\end{array}$ \\
\hline $\begin{array}{l}\text { Pierwotny skórny agresywny } \\
\text { chłoniak epidermotropowy } \\
\text { z cytotoksycznych komórek CD } 8(+) \\
\text { i pierwotny skórny chłoniak } \\
\text { z komórek T } \gamma / \delta\end{array}$ & $\begin{array}{l}\text { Brak wystarczających danych } \\
\text { do rekomendowania leczenia }\end{array}$ & $\begin{array}{l}\text { Opcja lecznicza dla postaci zaawansowanej, } \\
\text { pacjentów w młodym wieku, w dobrym stanie } \\
\text { ogólnym, bez istotnych schorzeń towarzyszących }\end{array}$ \\
\hline $\begin{array}{l}\text { Pierwotny skórny chłoniak anapla- } \\
\text { styczny z dużych komórek CD30+ }\end{array}$ & $\begin{array}{l}\text { Brak wystarczających danych } \\
\text { do rekomendowania leczenia }\end{array}$ & Opcja lecznicza dla postaci opornych na leczenie \\
\hline \multicolumn{3}{|c|}{ Pierwotne chłoniaki skóry z komórek B } \\
\hline $\begin{array}{l}\text { Pierwotny skórny chłoniak rozlany } \\
\text { z dużych komórek B typu kończy- } \\
\text { nowego }\end{array}$ & $\begin{array}{l}\text { Opcja lecznicza dla postaci } \\
\text { opornych lub nawrotowych }\end{array}$ & $\begin{array}{l}\text { Brak wystarczających danych do rekomendowania } \\
\text { leczenia }\end{array}$ \\
\hline $\begin{array}{l}\text { Pozostałe pierwotne chłoniaki } \\
\text { skóry z komórek B }\end{array}$ & $\begin{array}{l}\text { Brak wystarczających danych } \\
\text { do rekomendowania leczenia }\end{array}$ & $\begin{array}{l}\text { Brak wystarczających danych do rekomendowania } \\
\text { leczenia }\end{array}$ \\
\hline
\end{tabular}

(karmustyna, etopozyd, Ara-C, melfalan) lub połączenie radioterapii $z$ chemioterapią, na przykład TBI, etopozyd, cyklofosfamid $[4,10]$.

Pierwotny skórny agresywny chłoniak epidermotropowy $\mathbf{z}$ cytotoksycznych komórek CD8(+) i pierwotny skórny chłoniak z komórek $\mathrm{T} \gamma / \delta$

Pierwotny skórny agresywny chłoniak epidermotropowy z cytotoksycznych komórek CD8(+) (AECTCL, primary cutaneous aggressive epidermotropic cytotoxic CD8 positive T cell lymphoma) i pierwotny skórny chłoniak $z$ komórek $\mathrm{T} \gamma / \delta$ (PCGD-TCL, primary cutaneous gamma-delta T-cell lymphoma) są bardzo rzadkimi nowotworami o agresywnym lub bardzo agresywnym przebiegu. Ze względu na małą liczbę opisanych przypadków optymalne leczenie nie zostało dotychczas ustalone. Zwykle stosuje się terapie oparte na polichemioterapii (np. CHOP), a u pacjentów bez przeciwwskazań rozważa się przeprowadzenie allo-HSCT, zgodnie $z$ zasadami przedstawionymi $\mathrm{w}$ odniesieniu do MF/SS [4, 19-21].

Pierwotny skórny chłoniak anaplastyczny z dużych komórek CD30+

Pierwotny skórny chłoniak anaplastyczny $z$ dużych komórek CD30+ (C-ALCL, primary cutaneous anaplastic large cell lymphoma) to rzadki chłoniak pierwotnie zajmujący skórę, czasem $z$ wtórnym zajęciem węzłów chłonnych. W postępowaniu stosuje się leczenie chirurgiczne, radioterapię, a w przypadku wtórnego zajęcia narządowego - polichemioterapię (np. CHOP), interferon, beksaroten lub brentuksymab vedotin (przeciwciało monoklonalne anty-CD30 sprzężone $z$ kalichemicyną).

W literaturze można znaleźć pojedyncze opisy wykorzystania allo-HSCT w przypadkach oporności choroby. W kondycjonowaniu stosowano wówczas RIC (2 Gy TBI i fludarabinę) lub MAC (TBI, etopozyd). W obu przypadkach uzyskano $\mathrm{CR}$ trwającą minimum rok $[22,23]$.

Rola transplantacji w leczeniu pierwotnych chłoniaków skóry z komórek B

Pierwotne chłoniaki skóry wywodzące się $z$ limfocytów B są bardzo rzadkimi chorobami. Większość $\mathrm{z}$ nich przebiega $\mathrm{w}$ sposób łagodny. W leczeniu stosuje się zazwyczaj metody chirurgiczne, radioterapię [4, 24, 25], a w przypadku schorzeń związanych $z$ infekcją bakteryjną — antybiotykoterapię [26]. W wyjątkowych przypadkach, tj. w postaciach uogólnionych, przy dużym zaawansowaniu choroby stosuje się chemioterapię [4]. Brakuje rekomendacji dotyczących stosowania jakiejkolwiek formy transplantacji krwiotwórczych komórek macierzystych. 
Nieco inne leczenie stosuje się w przypadku pierwotnego skórnego chłoniaka rozlanego $z$ dużych komórek B typu kończynowego, w którym rokowanie jest poważne. Zgodnie $z$ rekomendacjami NCCN postępowanie jest podobne jak $\mathrm{w}$ innych podtypach chłoniaków rozlanych $z$ dużych komórek B. Procedura auto-HSCT z krwi obwodowej stanowi opcję leczniczą w przypadku oporności lub nawrotu choroby, jeżeli nie ma istotnych przeciwwskazań do intensywnej chemioterapii (mediana wieku przy rozpoznaniu wynosi 70 lat). W tych przypadkach w leczeniu kondycjonującym wykorzystuje się schemat BEAM.

\section{Podsumowanie}

Przeszczepienie krwiotwórczych komórek macierzystych jest uznaną metodą leczenia wielu schorzeń nowotworowych i nienowotworowych. Podstawą wskazań do tej metody u chorych na pierwotne chłoniaki skóry są głównie opinie ekspertów, wsparte bardzo skąpymi danymi klinicznymi. Różnią się w one odniesieniu do auto-HSCT i allo-HSCT, a także w zależności od podtypu histopatologicznego. Uwzględniając dostępne dane, wskazania do transplantacji podano w tabeli 4 .

Postęp w zakresie stosowania HSCT u chorych na pierwotne chłoniaki skóry zależy w dużym stopniu od właściwej współpracy specjalistów zajmujących się leczeniem tej grupy chorych, tj. hematologów, dermatologów i transplantologów. Wyniki terapii mogą zależeć od właściwego doboru leczenia kondycjonującego oraz protokołu immunosupresji, co - z kolei - jest uwarunkowane doświadczeniem personelu danego ośrodka. Istnieje potrzeba weryfikacji skuteczności i bezpieczeństwa stosowanych procedur $\mathrm{w}$ prospektywnych badaniach klinicznych.

\section{Piśmiennictwo}

1. Willemze R, Jaffe ES, Burg G, et al. WHO-EORTC classification for cutaneous lymphomas. Blood. 2005; 105(10): 3768-3785, doi: 10.1182/blood-2004-09-3502, indexed in Pubmed: 15692063.

2. Swerdlow SH, Campo E, Harris NL, et al. WHO classification of tumours of hematopoietic and lymphoid tissues. IARC. 2008: 179-317.

3. van Doorn R, Van Haselen CW, van Voorst Vader PC, et al. Mycosis fungoides: disease evolution and prognosis of 309 Dutch patients. Arch Dermatol. 2000; 136(4): 504-510, doi: 10.1001/ /archderm.136.4.504, indexed in Pubmed: 10768649.

4. Sokołowska-Wojdyło M, Lech-Marańda E, Placek W, et al. w imieniu Polskiej Grupy Badawczej Chłoniaków. Leczenie pierwotnych chłoniaków skóry. Rekomendacje Sekcji Chłoniaków Skóry Polskiej Grupy Badawczej Chłoniaków (PLRG). Onkol Prak Klin. 2010; 6(1): 29-47.
5. Fierro MT, Quaglino P, Savoia P, et al. Systemic polychemotherapy in the treatment of primary cutaneous lymphomas: a clinical follow-up study of 81 patients treated with COP or CHOP. Leuk Lymphoma. 1998; 31(5-6): 583-588, doi: 10.3109/10428199809057618, indexed in Pubmed: 9922049.

6. Akpek G, Koh HK, Bogen S, et al. Chemotherapy with etoposide, vincristine, doxorubicin, bolus cyclophosphamide, and oral prednisone in patients with refractory cutaneous T-cell lymphoma. Cancer. 1999; 86(7): 1368-1376, doi: 10.1002/(sici)10970142(19991001)86:7<1368::aid-cncr37>3.3.co;2-\#, indexed in Pubmed: 10506727.

7. Mebazaa A, Dupuy A, Rybojad M, et al. ESHAP for primary cutaneous T-cell lymphomas: efficacy and tolerance in 11 patients. Hematol J. 2005; 5(7): 553-558, doi: 10.1038/sj.thj.6200570, indexed in Pubmed: 15692599.

8. Bigler RD, Crilley P, Micaily B, et al. Autologous bone marrow transplantation for advanced stage mycosis fungoides. Bone Marrow Transplant. 1991; 7(2): 133-137, indexed in Pubmed: 2049557.

9. Olavarria E, Child F, Woolford A, et al. T-cell depletion and autologous stem cell transplantation in the management of tumour stage mycosis fungoides with peripheral blood involvement. Br J Haematol. 2001; 114(3): 624-631, doi: 10.1046/j.13652141.2001.02919.x, indexed in Pubmed: 11552988.

10. Duarte RF, Schmitz N, Servitje O, et al. Haematopoietic stem cell transplantation for patients with primary cutaneous T-cell lymphoma. Bone Marrow Transplant. 2008; 41(7): 597-604, doi: 10.1038/sj.bmt.1705968, indexed in Pubmed: 18176611.

11. Goldstein SC, Porter DL. Allogeneic immunotherapy to optimize the graft-versus-tumor effect: concepts and controversies. Expert Rev Hematol. 2010; 3(3): 301-314, doi: 10.1586/ehm.10.29, indexed in Pubmed: 21082981.

12. Molina A, Zain J, Arber DA, et al. Durable clinical, cytogenetic, and molecular remissions after allogeneic hematopoietic cell transplantation for refractory Sezary syndrome and mycosis fungoides. J Clin Oncol. 2005; 23(25): 6163-6171, doi: 10.1200/ /JCO.2005.02.774, indexed in Pubmed: 16135483.

13. Delioukina M, Zain J, Palmer JM, et al. Reduced-intensity allogeneic hematopoietic cell transplantation using fludarabine-melphalan conditioning for treatment of mature T-cell lymphomas. Bone Marrow Transplant. 2012; 47(1): 65-72, doi: 10.1038/ /bmt.2011.16, indexed in Pubmed: 21358679.

14. Paralkar VR, Nasta SD, Morrissey K, et al. Allogeneic hematopoietic SCT for primary cutaneous T cell lymphomas. Bone Marrow Transplant. 2012; 47(7): 940-945, doi: 10.1038/bmt.2011.201, indexed in Pubmed: 22020023.

15. Duvic M, Donato M, Dabaja B, et al. Total skin electron beam and non-myeloablative allogeneic hematopoietic stem-cell transplantation in advanced mycosis fungoides and Sezary syndrome. J Clin Oncol. 2010; 28(14): 2365-2372, doi: 10.1200/JCO.2009.25.8301, indexed in Pubmed: 20351328.

16. Duarte RF, Boumendil A, Onida F, et al. Long-term outcome of allogeneic hematopoietic cell transplantation for patients with mycosis fungoides and Sézary syndrome: a European society for blood and marrow transplantation lymphoma working party extended analysis. J Clin Oncol. 2014; 32(29): 3347-3348, doi: 10.1200/JCO.2014.57.5597, indexed in Pubmed: 25154828.

17. Lechowicz MJ, Lazarus HM, Carreras J, et al. Allogeneic hematopoietic cell transplantation for mycosis fungoides and Sezary syndrome. Bone Marrow Transplant. 2014; 49(11): 1360-1365, doi: 10.1038/bmt.2014.161, indexed in Pubmed: 25068422. 


\section{Hematologia 2017, tom 8, nr 4}

18. Whittaker S, Hoppe R, Prince HM. How I treat mycosis fungoides and Sézary syndrome. Blood. 2016; 127(25): 3142-3153, doi: 10.1182/blood-2015-12-611830, indexed in Pubmed: 27151889.

19. Burg G, Dummer R, Wilhelm M, et al. A subcutaneous delta-positive T-cell lymphoma that produces interferon gamma. N Engl J Med. 1991; 325(15): 1078-1081, doi: 10.1056/ /NEJM199110103251506, indexed in Pubmed: 1832485.

20. Toro JR, Liewehr DJ, Pabby N, et al. Gamma-delta T-cell phenotype is associated with significantly decreased survival in cutaneous T-cell lymphoma. Blood. 2003; 101(9): 3407-3412, doi: 10.1182/blood-2002-05-1597, indexed in Pubmed: 12522013.

21. de Wolf-Peeters C, Achten R. gammadelta T-cell lymphomas: a homogeneous entity? Histopathology. 2000; 36(4): 294-305, doi: 10.1046/j.1365-2559.2000.00893.x, indexed in Pubmed: 10759943.

22. Fijnheer R, Sanders CJG, Canninga MR, et al. Complete remission of a radiochemotherapy-resistant cutaneous T-cell lymphoma with allogeneic non-myeloablative stem cell transplantation. Bone Marrow Transplant. 2003; 32(3): 345-347, doi: 10.1038/ /sj.bmt.1704136, indexed in Pubmed: 12858211.
23. Pérez-Persona E, Mateos-Mazón JJ, López-Villar O, et al. Complete remission of subcutaneous panniculitic T-cell lymphoma after allogeneic transplantation. Bone Marrow Transplant. 2006; 38(12): 821-822, doi: 10.1038/sj.bmt.1705527, indexed in Pubmed: 17057727 .

24. Zenahlik P, Fink-Puches R, Kapp KS, et al. [Therapy of primary cutaneous B-cell lymphomas]. Hautarzt. 2000; 51(1): 19-24, indexed in Pubmed: 10663035.

25. Kirova YM, Piedbois Y, Le Bourgeois JP. Radiotherapy in the management of cutaneous B-cell lymphoma. Our experience in 25 cases. Radiother Oncol. 1999; 52(1): 15-18, doi: 10.1016/s01678140(99)00089-4, indexed in Pubmed: 10577681.

26. Kütting B, Bonsmann G, Metze D, et al. Borrelia burgdorferi-associated primary cutaneous B cell lymphoma: complete clearing of skin lesions after antibiotic pulse therapy or intralesional injection of interferon alfa-2a. J Am Acad Dermatol. 1997; 36(2 Pt 2): 311-314, doi: 10.1016/s0190-9622(97)80405-7, indexed in Pubmed: 9039207. 